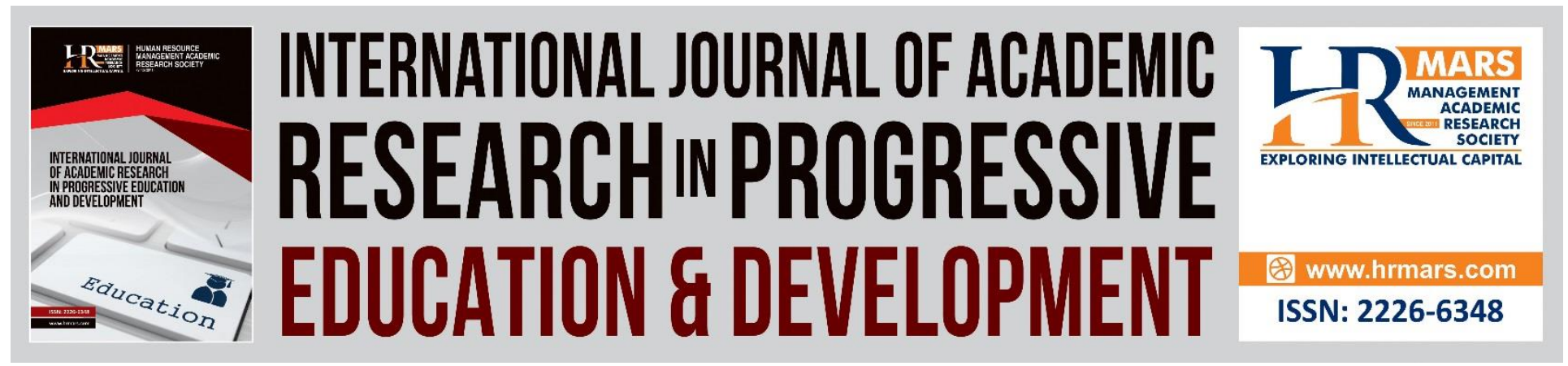

\title{
Examining the Role of Anxiety, Self-efficacy, and Motivation in the Vocabulary Performance among MFL Learners
}

Suo Yan Ju, Suo Yan Mei

To Link this Article: http://dx.doi.org/10.6007/IJARPED/v10-i1/8954

DOI:10.6007/IJARPED/v10-i1/8954

Received: 16 February 2021, Revised: 18 March 2021, Accepted: 31 March 2021

Published Online: 05 April 2021

In-Text Citation: (Ju \& Mei, 2021)

To Cite this Article: Ju, S. Y., \& Mei, S. Y. (2021). Examining the Role of Anxiety, Self-efficacy, and Motivation in the Vocabulary Performance among MFL Learners. International Journal of Academic Research in Progressive Education and Development, 10(1), 507-521.

Copyright: (c) 2021 The Author(s)

Published by Human Resource Management Academic Research Society (www.hrmars.com)

This article is published under the Creative Commons Attribution (CC BY 4.0) license. Anyone may reproduce, distribute, translate and create derivative works of this article (for both commercial and non-commercial purposes), subject to full attribution to the original publication and authors. The full terms of this license may be seen at: http://creativecommons.org/licences/by/4.0/legalcode

Vol. 10(1) 2021, Pg. 507 - 521

http://hrmars.com/index.php/pages/detail/IJARPED

JOURNAL HOMEPAGE

Full Terms \& Conditions of access and use can be found at http://hrmars.com/index.php/pages/detail/publication-ethics 


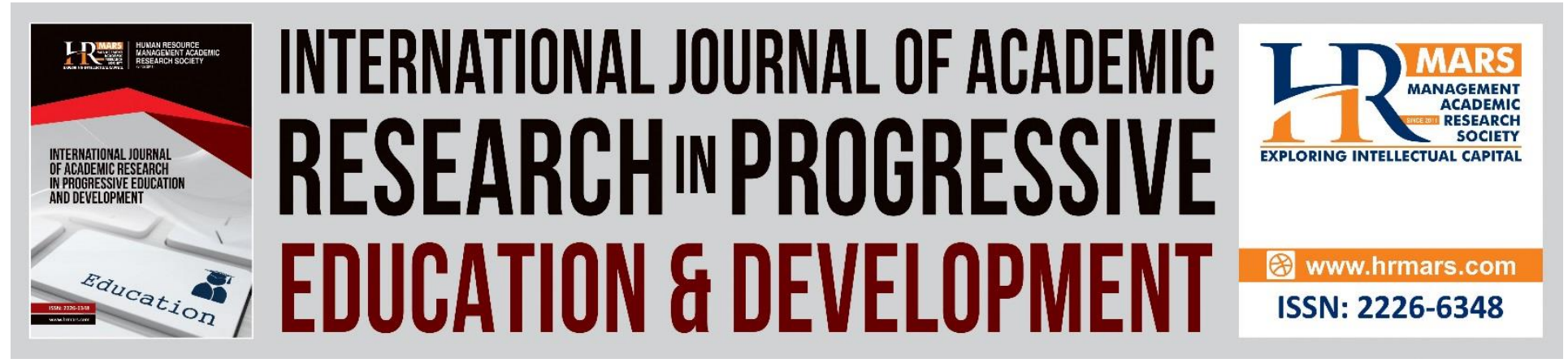

\title{
Examining the Role of Anxiety, Self-efficacy, and Motivation in the Vocabulary performance among MFL learners
}

\author{
Suo Yan Ju \\ Faculty of Major Language Studies, Universiti Sains Islam Malaysia \\ Email: suoyanju@usim.edu.my
}

Suo Yan Mei

Faculty of Languages and Communication Universiti Pendidikan Sultan Idris

Email: mys71fa@gmail.com

\begin{abstract}
Vocabulary is the key to make communication possible, learners need to acquire adequate vocabulary to help them to communicate appropriately with the target language. to learn Chinese, a foreign learner must have a grasp of a large vocabulary sufficient for communication. This quantitative study examined the potential relationship between foreign language Motivation, Language anxiety, and self-efficacy, and achievement in Mandarin Chinese vocabulary. 98 Malay-speakers of Mandarin Chinese language novice learners in a public university in Malaysia participated in the study. An unannounced vocabulary test was used to check participants' Mandarin Chinese vocabulary performance. The learning motivation, Language anxiety, and self-efficacy were measured by specifically designed instruments that targeted Mandarin Chinese vocabulary acquisition. A multiple linear regression analysis revealed that language anxiety and self-efficacy were positive and significant determinants of Mandarin Chinese vocabulary performance, although motivation was not. This confirms that the learners' affective feature plays a role in Mandarin Chinese vocabulary acquisition.
\end{abstract}

Keywords: Anxiety, Mandarin Chinese, Self-Efficacy, Motivation, Vocabulary, Performance.

\section{Introduction}

Since 1968 Malaysia high institutions offered Mandarin Chinese as a foreign or third language. The Malaysia Education Blueprint 2015-2025 (Higher Education) also encourages high learning institution students to master one global language (such as Mandarin, Japanese, French and Spanish) beside national language and English language. (Ministry of high education Malaysia, 2013) To be proficient in a global language will benefit graduates to easily get access 
to the latest technology and information and will also add advantage in multicultural and diverse work environments whereby more opportunities are opened for them that can be competent with their peers in Malaysia context. The purposes of Mandarin Chinese courses have been offered in all Public high institution in Malaysia are to help enhance employment opportunities among their graduates, and that the universities also place the importance on mastering multiple languages skills for graduate able to compete in the workplace (Hoe,2017). Besides that, Mandarin Chinese is one of the languages widely used among Malaysian Chinese and local Chinese schools in Malaysia and other countries except for International language English (Wang,2016). Therefore, Mandarin Chinese became a very popular third language to be taken in high institutions among undergraduates. Fan (2011) states that currently, Mandarin Chinese is the most preferred language among the foreign language offered in the high institution in Malaysia. To fulfil the high demand in the market, and help graduates in their future careers (Tan.et.al, 2012) all public universities and other government technological and vocational colleges have offered Mandarin Chinese to Non-Chinese university students. However, desired learning outcomes have not been achieved. (Tan et al., 2016) It has been confirmed by Naimah (2005, as cited in Tan et al.,2016) that many foreign language learners cannot communicate in the target language.

\section{Chinese words/vocabulary}

A word/vocabulary in Mandarin Chinese language refers to individual characters with independent meanings, comprise of one or two or more than two characters. In the Mandarin Chinese language, there are $6 \%$ are single-character words, $72 \%$ are two-character words, $12 \%$ are three-character words, and $10 \%$ are four-character words (Li et al. 2014). Because the numbers of two-character and three-character words significantly exceed the number of singlecharacter words, the examination of Chinese words focuses on multi-character words henceforth.

Most Mandarin Chinese words are made up of two or more morphemes; many morphemes are used recurrently in constructing compound words. There are more words than characters in Mandarin Chinese. There are 20959 characters and 520000 words have been included in the online Xinhua Chinese dictionary currently.

Knowing how to use the words means one needs to know its grammatical functions, collocations, and constraints. Many scholars and TCSL teachers have done much work on the teaching methods and strategies of teaching Chinese as a second language (TCSL). And articles focusing on this question can be seen in various periodicals. Hu (2000) has discussed "Some Questions in Vocabulary Teaching in TCSL" (p.291), he mainly discussed the teaching strategies in different stages (elementary, intermediate, and advanced levels). Li \& Yang (2004) holds that "vocabulary teaching should be the focus of teaching Chinese as a Second Language" (p.21-29). Guo (2010) has introduced the idea of a "Concept Map" (p.23) in teaching Chinese words to midlevel learners. All these are good attempts to enlarge the students' vocabulary and to improve the teaching efficiency, yet these papers are either too abstract to instruct the teaching activity or too complicated to operate. So, the teaching methods of vocabulary in TCSL should be given serious reflection, and it is also worthwhile to explore the methods and strategies to enlarge the learners' vocabulary. 


\section{Problem Statement}

Master Mandarin Chinese is different compared to the Malay or English language due to the unique Chinese characters' writing system. To understand Mandarin Chinese fully learners must learn three distinctive elements: sound, shape, and meaning that makes it difficult for Malay L3 language learners whose first and second language are both adapted Romanized system. There could be many factors that affect learners' learning outcome due to the learners' interference of their mother tongue, a non-conducive learning environment and insufficient learning time, teaching method or strategies, lack of motivation, lack of vocabulary (Chen et al., 2010) could be other factors cause learner facing learning problems. Tan and Hoe (2007) argued that lacking vocabulary is one of the causes that learners cannot communicate effectively in the target language, they suggested that more studies need to be carried out to investigate the learners' psychological factors of Mandarin Chinese vocabulary acquisition such as learners' learning motivation, self-efficacy, Language learning anxiety.

Expect the natural of target language cause learning difficulties, other factors affect language learners' performance attracted many educators and researchers' attention. The study discovered there is a correlation between affective factors such as anxiety. (Zhao \& Whitchurch,2011; Han, 2015). These studies have been done in western countries and are not really focused on non-native speakers. The studies found that self-efficacy plays a role in foreignlanguage performance. However, the impact of learners' Self-efficacy on Mandarin as a foreign language did not attract much attention. The correlation between the factors on the Mandarin Chinese performance, especially on vocabulary performance is under discovering. Therefore, the current study aims to fill up this gap to investigate the relationship between psychological factors and the Mandarin Chinese vocabulary performance among Malay novice learners in the high institution in Malaysia.

The current study tends to answer the following Research questions:

1. Does language anxiety play the role on learners' vocabulary performance among Mandarin Chinese foreign language learners at public university in Malaysia?

2. Does self-efficacy play the role on learners' vocabulary performance among Mandarin Chinese foreign language learners at public university in Malaysia?

3. Does language learning motivation play the role on learners' vocabulary performance among Mandarin Chinese foreign language learners at public university in Malaysia?

we propose the following hypotheses:

$\mathrm{HO}$ : language anxiety has no effect on the vocabulary performance among Mandarin Chinese foreign language learner at public university in Malaysia.

Ha: language anxiety has positive effect on vocabulary performance among Mandarin Chinese foreign language learner at public university in Malaysia.

HO: Self-efficacy has no effect on the vocabulary performance among Mandarin Chinese foreign language learner at public university in Malaysia. 
Vol. 10, No. 1, 2021, E-ISSN: 2226-6348 @ 2021 HRMARS

Ha: self-efficacy has positive effect on vocabulary performance among Mandarin Chinese foreign language learner at public university in Malaysia

HO: language learning motivation has no effect on the vocabulary

performance among Mandarin Chinese foreign language learner at public university in Malaysia.

Ha: language learning motivation has positive effect on vocabulary performance among Mandarin Chinese foreign language learner at public university in Malaysia

\section{Literature Review}

\section{Language anxiety and foreign/ second language learning}

Anxiety as the psychological factors in which foreign language learner goes through while they carry out the learning task. (Zhang, 2001) It is one of the factors that affect foreign language learners' performance. There were many studies English as foreign language anxiety.

Dalkilic (2001) examined learners' foreign language anxiety levels and their performance in the speaking courses. The study discovered that learners' foreign language anxiety levels increased, their grades turn out to be high. Batumlu and Erden (2007) conducted a study among university Turkish learners of English as foreign language anxiety and achievement by using the Foreign language anxiety scale (FLCAS) and semester test results. The study demonstrated that there was a significant negative relationship between foreign language anxiety and learners' English achievement. The studies of foreign language anxiety related to Mandarin Chinese are limited. Han (2013) explored the Chinese foreign language (CFL) learners' anxiety at U.S university. The study only discovered that Chinese language learning anxiety is not that high compare to other foreign language in the previous studies. However, this study did not explore the relationship between the anxiety and learner's performance.

\section{Motivation and second/foreign language learning}

The studies of Motivation have been influenced by various theories. Skinner's conditioning theory argued that if give students promised rewards in form of praise or grade, they are motived to complete the given tasks (Anjomshoa \& Sadighi,2015). The cognitive view looked at the environment and self-concept influence people's motivation. In Piaget's view (as cited in Anjomshoa \& Sadighi, 2015) students may become motivated to learn to achieve desired equilibrium and obtain a feeling of mastery over their environment.

In language learning, Gardner's (2001) motivation theory has been extremely influential in the L2 motivation field for decades. Garger (2005) claimed in his socio-educational model that motivation and ability (including intelligence and language aptitude) are strongly linked to an individual's language learning achievement.

Motivation is a major factor in language learning and is an important contributor to language performance in terms of linguistics that including language structure: vocabulary, grammar pronunciation, and four basic skills. (Gardner, 1985 as cited in Anjomshoa \& Sadighi, 2015). 


\section{Self-efficacy and foreign/ second language learning}

One of the important concepts in Bandura's social cognitive theory is self-efficacy that refers to an individual's self-belief in his or her own ability to complete the given task. Studies discovered that learners with high self-efficacy may lead to an increase in learners' engagement and perform better in their academics compared to those with low self-efficacy (Ahmad \& Safaria, 2013; Mohamed \&Yunus, 2017).

There is a lot of research has been conducted on learning, but researchers only paid attention to the effect on the second language in the last ten years. Research results demonstrated selfefficacy is a key factor that affects learners' interests, goals they choose to strive for, performing tasks, and self-regulated strategies. (Carmichael \& Taylor, 2005. Linnenbrink \& Pintrich, 2003;) According to Lee, Puig, Kim, Shin, Lee \& Lee (2010), students who function well in the higher education environment will have high academic efficacy and low emotional exhaustion and cynicism. On the other hand, higher self-efficacy will lead to an increase in engagement among students, which will enhance their performance (Bresó, Schaufeli \& Salanova, 2011).

In foreign language learning contexts, most of the studies have investigated the correlational relationship between learners' self-efficacy beliefs and these variables, and only a few studies have focused on the causal relationship between self-efficacy and the mentioned variables. Among those researchers, according to (Saeid.et.al,2012) most consistent study tries to discover the foreign language learners 'self-efficacy affects language performance in general. (Rahimi\& Abedini 2009; Hsieh and Kang 2010; Mills, Pajares, \& Herron, 2007, Tilfarlioğlu \& Cınkara, 2011). The self-efficacy effects on vocabulary performance rarely explored.

\section{Methodology \\ Research Design}

This study used quantitative research in the sense of quantitative data is produced. The data was collected through a quantitative survey from 98 participants who were enrolled in a Mandarin course at a public university in Malaysia. The quick and easy convenience samples were implemented. The collected data analysed statistically by using Statistical Package for the Social Sciences (SPSS)

\section{Participants}

A sample of 98 first-year students from the Faculty of Major language studies, University science Islam Malaysia (USIM) voluntarily participated in this study. These convenience samples were participated in answering the questionnaires to give every individually targeted population the opportunity to be selected which eventually gives credibility to the study. These students were $30.6 \%(n=30)$ males and 69.4\% $(n=68)$ females. As for the respondents' age, $70.4 \%(n=69)$ of respondents were between 20 years old, while $27.6 \%$ of students ( $n=27$ ) were between 21 to 22 years old and $2 \%$ of students $(n=2)$ were between 23 to 24 years old. As for respondents' STPM results, $56.1 \%(n=55)$ of respondents have achieved second class upper, while $44.9 \%(n=43)$ of respondents have achieved second class lower. 


\begin{tabular}{|c|c|c|c|}
\hline \multicolumn{2}{|c|}{ Items } & No of participants & Percentage \\
\hline \multirow{4}{*}{ Age } & 20 years old & 69 & $70.4 \%$ \\
\cline { 2 - 4 } & 21 to 22 years old & 27 & $27.6 \%$ \\
\cline { 2 - 4 } & $23-24$-year-old & 2 & $2 \%$ \\
\hline \multirow{3}{*}{ Gender } & Male & 30 & $30.6 \%$ \\
\cline { 2 - 4 } & Female & 68 & $69.4 \%$ \\
\hline \multirow{2}{*}{ Results of STPM } & Second class upper & 55 & $44.9 \%$ \\
\cline { 2 - 4 } & Second class lower & 43 & \\
\hline
\end{tabular}

\section{Instruments}

There are two parts included in the instrument: participants' personal information and scales. participants' personal information consisted of 4 distinctive questions: Gender, age, year of study, CGPA. The scales with dimensions: 10 items of Mandarin Chinese self-efficacy, 10 items of learning motivation, and 10 items of language anxiety. This scale was adopted and modified from Luo's (2013) Mandarin Chinese language anxiety scale, Bandura's (2006) English language learning self-efficacy scale, and foreign language learning motivation scale. A pilot survey with 10 participants was carried out, and the questionnaire was further improved based on the results and expert advice.

To examine the role of language anxiety, self-efficacy, and motivation in learning Mandarin Chinese as a foreign language. The internal consistency of the scale was investigated through Cronbach's alpha and the result indicated that it is suitable to be used for any meaningful academic exercises. The Cronbach's alpha was ranged between.73 to .90 which suggested that the scale is psychometrically sound and can be used for this research activity. The questionnaire was then distributed to the participants and they were asked to define the degree to which they agree or disagree with each item in the questionnaire rated from 1 to 7 used the Liker-style scale.

\section{Chinese Vocabulary Test}

In this study, an unannounced vocabulary test with the 20 target words was administered to participants after they complete three Mandarin Chinese lessons. The Mandarin Chinese vocabulary tested are the words participants learned in lessons listed in random order. The participants need to circle its pronunciation and English meaning, At the end of the test, participants need to construct one sentence for each word give. one mark gives to each correct 
answer. By doing this to check participants' true knowledge of Mandarin Chinese vocabulary. Because true vocabulary knowledge acquisition requires full vocabulary knowledge what involves knowing a word's form, its meaning, syntactic behaviours, and relation with other words. (Laufer \& Paribakht, 1998). All participants reported do not know any Mandarin Chinese vocabulary encountering them before they study the targeted words.

\section{Procedure}

The data of this study were collected during the normal class time in semester I 2019/2020 academic year. The researcher informed participants about the objective of the study. The researcher explained to participants that the test results would not impact their final course grades. Participants completed the test in 30 minutes towards the end of the lesson. The researcher collected the test paper after they completed it. The survey questionnaire with three components: Chinese vocabulary learning motivation, anxiety, and self-efficacy was completed before the semester end.

The researcher marked the test and recorded the results by using a rubric created by Laufer and Hulstijin (2001). Students obtained one point by giving both answers in Pinyin and English meaning) and students obtained half a point only give an answer either Pinyin(pronunciation) or English meaning. Students obtain zero points there were no answers. Two pints were assigned if the participants constructed simple sentences with the words in pinyin form. At the end of the Mandarin Chinese vocabulary test, the scores of this study were then calculated, the total scale mean scores were used in the analysis.

\section{Data Analysis Method}

IBM Statistical Package for the Social Sciences (SPSS) 24.0 was used to conduct the required statistical descriptive and correlation analyses were used to analysed all the variables. Correlation and multiple linear regression (MLR) analysis were conducted to examine the relationship between Mandarin Chinese vocabulary acquisition among Malay novice learners and various potential predictors: vocabulary learning motivation, Language anxiety, and self-efficacy.

\section{Findings}

Descriptive statistics of all variables are presented in Table 1 and Table 2. The data showed that participants acquired an average of 11.74 out of 20 Mandarin Chinese vocabulary given (SD= 2.6) after three lessons. The participants' average Mandarin Chinese vocabulary test score was $78 \%$. Participants were moderately motivated to acquire Chinese vocabulary from the lessons have been thought as measured by Chinese Vocabulary learning motivation ( $M=6.57, S D=2.18$ ). The self-efficacy affection of Mandarin Chinese vocabulary acquisition is reported and measured by self-efficacy $(M=6.23, S D=1.43)$. A report of language anxiety affects their Mandarin Chinese vocabulary acquisition measured by language anxiety $(M=4.7, S D=0.71)$.

Table 1. Test result

\begin{tabular}{cccc}
\hline Variables & $\mathrm{M}$ & SD & ACERAGE \\
\hline Mandarin Chinese vocabulary test score & 11.74 & 2.6 & $78 \%$ \\
\hline
\end{tabular}


INTERNATIONAL JOURNAL OF ACADEMIC RESEARCH IN PROGRESSIVE EDUCATION AND

DEVELOPMENT

Vol. 10, No. 1, 2021, E-ISSN: 2226-6348 @ 2021 HRMARS

Table 2. Descriptive Statistics for Main Study Variables

\begin{tabular}{lll}
\hline \multicolumn{1}{c}{ Variables } & M & SD \\
\hline Chinese vocabulary learning motivation & & 2.18 \\
Language anxiety & 6.58 & 0.71 \\
Self-efficacy & 4.77 & 1.43 \\
\hline
\end{tabular}

Correlation and multiple linear regression (MLR) analysis were conducted to examine the relationship between Mandarin Chinese vocabulary acquisition by Malay novice learners and

various potential predictors: vocabulary learning motivation, Language anxiety, and selfefficacy. The assumptions of MLR were first checked before running the MLR. The histogram

and scatterplot of standardized residuals indicated that the assumptions of normality, homogeneity of variances, and linearity all met. The assumption of independent errors was also met (Durbin-Watson value=1.62). Tests for multi-collinearity indicated that multicollinearity was not a concern (VIF= 1.01 for vocabulary learning motivation, 1.04 for Language anxiety, and 1.47 for self-efficacy).

Results showed that Language anxiety $(\beta=.37, t=4.39, p<.05$, see Table 3$)$ and self-efficacy $(\beta=.106, t=1.05, p<.05)$ were significant positive predictors of Mandarin Chinese vocabulary acquisition with result $(\mathrm{F}(2,96)=4.03, \mathrm{p}<.000)$ with $R^{2}$ of .30 . Mandarin Chinese vocabulary learning motivation $(\beta=.02, t=0.17, p>.05)$ was not significant predictors of Mandarin Chinese vocabulary acquisition among Malay novice learners. Table 3. summarizes the multiple regression analysis results.

Table 3. Multiple regression linear analysis results

\begin{tabular}{lcccccc}
\hline \multicolumn{1}{c}{ Variables } & $\mathrm{B}$ & $\mathrm{SE} \mathrm{B}$ & $95 \% \mathrm{Cl}$ & $\beta$ & $\mathrm{t}$ & $P$ \\
\hline $\begin{array}{l}\text { Vocabulary learning } \\
\text { motivation }\end{array}$ & 0.14 & 0.670 & {$[0.03,1.16]$} & .02 & 0.17 & .024 \\
Self-efficacy & & & & & & \\
Language anxiety & 0.65 & 0.024 & {$[0.14,1.59]$} & .106 & 1.05 & .035 \\
\hline
\end{tabular}

Note. $\mathrm{R}^{2}=.37 \mathrm{~N}=98 \mathrm{Cl}=$ confidence interval to $\mathrm{B} P<.05$

\section{Discussions}

The purpose of the study was to investigate the several psychological factors that play the role in Mandarin Chinese vocabulary acquisition: Mandarin Chinese vocabulary learning motivation, language anxiety, and self-efficacy. The findings discovered that language anxiety and selfefficacy were positively correlated to Mandarin Chinese vocabulary learning among Malay speakers of Mandarin Chinese as a foreign language, but vocabulary learning motivation was not playing a role in their vocabulary learning. The study only included Malay-speakers who are learning Mandarin Chinese as a foreign language; therefore, the finding must be interpreted in this point.

The results indicated that Language anxiety and self-efficacy were significant predictors of Mandarin Chinese vocabulary acquisition among Malay novice learners. This is consistent with 
previous findings that foreign language anxiety usually affects L2 vocabulary acquisition (Zhao et al.,2016) L2 learners with higher levels of anxiety acquired fewer Mandarin Chinese words incidentally through lessons than those with lower language anxiety. Malay-speaker of Mandarin Chinese as a foreign language learner with lower language anxiety usually worries less about learning unfamiliar Mandarin Chinese words through class activities. However, Malay-speaker of Mandarin Chinese as foreign language learners with high levels and language anxiety worry more about the understanding of the meaning and pronunciation of Mandarin Chinese words.

Self-efficacy was another finding that corroborates previous studies reported to be strongly related to academic achievements by many researchers. (Boakye, Sommerville and Debusho 2014, Li 2012, Turner, Chandler and Heffer 2009). Li (2012) looked at the relationship between attitude, self-efficacy, and academic performance by using multiple regression analysis. Her study results showed that both attitude and self-efficacy could significantly predict academic achievement. Mizumoto (2012) studied the relationship between vocabulary learning strategies use and self-efficacy by EFL learners, the results showed that those with high self-efficacy were active users of vocabulary learning strategies (VLSs), they employed deep strategies, but those with low self-efficacy tended to be passive users of VLSs. The current study concludes that Malayspeakers of Mandarin Chinese novice learners with high self-efficacy are more active in learning Mandarin Chinese vocabulary and those who are low self-efficacy are passive learners in Mandarin Chinese vocabulary acquisition. The Mandarin Chinese language is different from the alphabet language. learners should have confidence and believes in themselves that with effort and practice they can master the Mandarin Chinese language.

Mandarin Chinese vocabulary learning motivation was the factor that did not significantly predict Mandarin Chinese vocabulary acquisition among Malay-speaker novice learners. That is high levels of motivation may not benefit Mandarin Chinese vocabulary acquisition. This finding confirmed studies of Zhao.et.al (2016) which is inconsistent with other studies that motivation was considered as a key factor in L2 acquisition (Dörnyei, 2009). This could be L2 motivation is continuously changing, evolving, and integrating with individual-level and environmental level variables (Waninge, Dörnyei \&De Bot, 2014). Malay-speakers' motivational level could like have fluctuated during the Mandarin Chinese vocabulary learning process may impact the relationship between Mandarin Chinese vocabulary acquisition and Mandarin Chinese vocabulary learning motivation. However, this assumption remains an empirical question and alternative explanations exist, further study of the possible predictive role of motivation in Mandarin Chinese vocabulary learning should be carried out in the future.

\section{Conclusion}

In conclusion, the results of the current study indicate that language anxiety and self-efficacy are positively predicted the Mandarin Chinese vocabulary acquisition by Mandarin Chinese language learners among Malay undergraduates. The finding provided essential implications for Mandarin Chinese vocabulary teaching and learning. The finding indicated that Malay-speakers of Mandarin novice learners with low language anxiety, high self-efficacy tend to learn more Mandarin Chinese vocabulary. Therefore, instructors should pay attention to affective factors by creating a conducive learning environment to lower learners' language anxiety and help learners 
to build more self-confidence in learning the Mandarin Chinese language especially Mandarin Chinese vocabulary which is a basic and very important component. Instructors should be aware learners' language anxiety levels will positively affect learners' Mandarin Chinese vocabulary acquisition. Instructors should guide learners to try to overcome the anxiety and build up their self-confidence to help them to improve vocabulary through different and attractive classroom activities and tasks.

The study cannot be free from limitations. Firstly, the study examined only Malay-speakers of Mandarin Chinese novice learners, therefore, it is not possible to determine whether the factors predicated Mandarin Chinese vocabulary acquisition at intermediate and advance level while learners learned more Mandarin Chinese words. Future studies should broaden the measurement to include other levels.

Secondly, Mandarin Chinese vocabulary acquisition was limited to the acquisition of words' meaning and pronunciation. Therefore, it is not possible to generalize these findings to the acquisition of other aspects of Mandarin Chinese vocabulary knowledge such as word forms, word collocation and syntactic features.

Thirdly, this study focused narrowly on learners' factors and left other important factors such as input factors, and word properties were not examined. Future studies should adopt a more comprehensive approach, investigating the interactions among these factors and their interactive effect on Mandarin Chinese vocabulary acquisition.

Fourthly, there are almost $70 \%$ of the participants of this study are females, the respondent gender is not equally distributed. therefore, the result of the study might be influenced by gender inequality. Future studies should include an equal number of both males and females among novice learners to examine that whether gender difference plays a role in Mandarin Chinese vocabulary acquisition.

Based on the findings of this study, it can be suggested that Mandarin language instructors should create a conducive learning environment that allows learners to experience positive learning experiences and feelings to build up their self-confidence so that the learners could engage more in their learning process. Besides, the study also provided some information for instructors about the effect of anxiety, self-efficacy, and engagement on learners ' vocabulary performance in Mandarin Chinese as a foreign language. The study can be replicated in other aspects of other foreign languages.

\section{References}

Ahmad, A., \& Safaria, T. (2013). Effects of Self-Efficacy on Students' Academic Performance. Journal of Educational, Health and Community Psychology, 2(1), 22-29. https://media.neliti.com/media/publications/135816-EN-effects-of-self-efficacy-onstudents-aca.pdf.

Anjomshoa, L., \& Sadighi, F. (2015). The Importance of Motivation in Second Language Acquisition. The Importance of Motivation in Second Language Acquisition, 3(2), 126-137. https://www.arcjournals.org/pdfs/ijsell/v3-i2/12.pdf. 
INTERNATIONAL JOURNAL OF ACADEMIC RESEARCH IN PROGRESSIVE EDUCATION AND

DEVELOPMENT

Vol. 10, No. 1, 2021, E-ISSN: 2226-6348 @ 2021 HRMARS

Asyiah, D. N. (2017). The vocabulary teaching and vocabulary learning: reception, strategies and influences on students' vocabulary mastery. Jurnal Bahasa Lingua Scientia, 9(2), 293319. https:// dx.doi.org/10.21274/ls.2017.9.2.293-318.

Bandura, A. (1997). Self-efficacy: The exercise of control. New York: W. H. Freeman and Company.

Bandura, A. (2006b). Guide to the construction of self-efficacy scales. In Pajares, F., Urdan, T. (Eds.), Self-efficacy beliefs of adolescents, 5, 307-337. Greenwich, CT: Information Age.

Batumlu, D. Z., \& Erden, M. (2007). The relationship between foreign language anxiety and English achievement of Yildiz technical university school of foreign languages preparatory students. Journal of Theory and Practice in Education, 3(1), 24-38.

Boakye, N. J., Sommerville, J., \& Debusho, L. K. (2014). The relationship between socio-affective factors and reading proficiency: Implications for Tertiary reading instruction. Journal for Language Teaching 48(1), 173-213.

Bresó, E., Salanova, M., \& Schaufeli, W. B. (2007). In search of the 'third dimension' of burnout: Efficacy or inefficacy? Applied Psychology: An International review, 56, 460-478.

Carmichael, C., \& Taylor, J. A. (2005). Analysis of student beliefs in a tertiary preparatory mathematics course. International Journal of Mathematical Education in Science and Technology, 36(7), 713-719. http://dx.doi.org/10.1080/00207390500271065

Chen, J. G., Wang, C., \& Cai, J. F. (2010). Teaching and Learning Chinese: Issues and Perspective. Charlotte, North Carolina: Information Age Publishing, Incorporated.

Cheong, K. M., Jano, Z., Salam, S., Bareed, N. A., Ithnin, F., \& Suraidi, N. (2019). Motivational Factors Among Undergraduates Learning Mandarin: A Qualitative Perspective." International Journal of Academic Research in Progressive Education and Development, (8) 2, 2019, 187-199., http://dx.doi.org/10.6007/IJARPED/v8-i2/5694

Dalkilic, D. (2001). The Role of Foreign Language Classroom Anxiety in English Speaking Courses. Çukurova Üniversitesi Sosyal Bilimler Enstitüsü Dergisi, 8(8), https://dergipark.org.tr/en/pub/cusosbil/issue/4364/59690

Dörnyei, Z. (2009). Motivation in second and foreign language learning. Language Teaching, 31(3), 117-135.http:// doi.org/10.1017/S026144480001315X

Elkhafaifi, H. (2005). Listening comprehension and anxiety in the Arabic language classroom. The Modern Language Journal, 89, 206-220. https://doi.org/10.1111/j.15404781.2005.00275.x.

Fan, P. S. (2011). The Dissemination and Development of Chinese Language in Malaysia- A Study on Current Status of Chinese Language Classes at Public Universities. Journal of Chinese Language Studies, 7, $242-248$.

Gardner, R. C. (2001). Integrative motivation and second language acquisition. In Dörnyei,Z., \& R. Schmidt (Eds.), Motivation and Second Language Acquisition (pp. 1-19). Hawaii: University of Hawaii Press.

Gardner, R. C. (2005). Integrative motivation and second language acquisition. Joint plenary talk at Canadian Association of Applied Linguistics/Canadian Linguistics Association.

Guo Rui. (2010). On the Strategy of “Concept Map" in Teaching of Mid-level Chinese Vocabulary. Language Teaching and Linguistic Studies.3, 23-28 
INTERNATIONAL JOURNAL OF ACADEMIC RESEARCH IN PROGRESSIVE EDUCATION AND

DEVELOPMENT

Vol. 10, No. 1, 2021, E-ISSN: 2226-6348 @ 2021 HRMARS

He Fengqiao. (1998). Attention Should Be Paid to Vocabulary Teaching. A Collection of Papers on Teaching Chinese as a Second Language. Shanghai: Shanghai Foreign Language Education Press. 82-93.

Hoe. F. T. (2017), Pertinent Information for Potential Mandarin Teachers in Malaysia. International Academic Research Journal of Social Science,3(1),37-41. http://www.iarjournal.com/wp-content/uploads/IARJSS2017_1_37-41.pdf.

Hsieh, P., \& Kang, H. (2010). Attribution and self-efficacy and their interrelationship in the Korean EFL context. Language Learning, 60(3), 606- 627. https://doi.org/10.1111/j.14679922.2010.00570.x

Hu Mingyang. (2000). Some Questions of Vocabulary Teaching in Teaching Chinese as a Second Language. Applied Linguistics. 1, 14-19.

Laufer, B., and Paribakht, T. S. (1998). The relationship between passive and active vocabularies: effects of language learning context. Language Learning, 48, 365-391.

Laufer, B., \& Hulstijn, J. (2001). Incidental vocabulary acquisition in a second language: The construct of task-induced involvement. Applied Linguistics, 22, 1-26.

https:// doi:10.1093/applin/22.1.1

Lent, R. W., Larkin, K. C., \& Brown, S. D. (1986). Self-efficacy in the prediction of academic performance and perceived career options. Journal of Counselling Psychology, 33(3), 265269.

Li, L. K. Y. (2012). A study of the attitude, self-efficacy, effort and academic achievement of CityU students towards research methods and statistics. Discovery, - SS Student EJournal1(1), 154-183. http://ssweb.cityu.edu.hk/download/RS/E-Journal/journal8.pdf

Li, X. S., Bicknell, K., Liu, P. P., Wei, W., Rayner, K. (2014) Reading is fundamentally similar across disparate writing systems: A systematic characterization of how words and characters influence eye movements in Chinese reading' Journal of Experimental Psychology General.143(2), 895-913.https://doi.org/ 10.1037/a0033580.

Linnenbrink, E. A., \& Pintrich, P. R. (2003). The role of self-efficacy beliefs in student engagement and learning in the classroom. Reading and Writing Quarterly: Overcoming Learning Difficulties, 19(2), 119-137. http://doi.org/ 10.1080/10573560308223.

Lee, J., Puig, A., Kim, Y.-B., Shin, H., Lee, J. H., \& Lee, S. M. (2010). Academic burnout profiles in Korean adolescents. Stress and Health: Journal of the International Society for the Investigation of Stress, 26(5), 404-416. https://doi.org/10.1002/smi.1312.

Lu Jianji. (1987). An Analysis of Errors in Foreigners' Study of Chinese Words and Expressions. Language Teaching and Linguistic Studies. 4, 124-134.

Luo, H. (2015). Chinese Language Learning Anxiety: A Study of Heritage Learners. Heritage Language Journal, 12(1), 22-47. https://doi.org/10.46538/hlj.12.1.2

Mills, N., Pajares, F., \& Herron, C. (2007). Self-efficacy of college intermediate French students: Relation to achievement and motivation. Language Learning, 57(3), 417442. https://doi.org/10.1111/j.1467-9922.2007.00421.x.

Mizumoto, A. (2012). Exploring the effects of self-efficacy on vocabulary learning strategies. Studies in Self-Access Learning Journal, 3(4), 423-437. http://sisaljournal.org/archives/dec12/mizumoto. 
INTERNATIONAL JOURNAL OF ACADEMIC RESEARCH IN PROGRESSIVE EDUCATION AND

DEVELOPMENT

Vol. 10, No. 1, 2021, E-ISSN: 2226-6348 @ 2021 HRMARS

Mohamed, W. H. S. W., \& Yunus, J. @. N. (2017). Self-Efficacy and Academic Performance of Secondary Schools Students in Perak: An Exploratory Outlook. International Journal of Academic Research in Progressive Education and Development, 6(3), 41-55. https://doi.org/10.6007/ijarped/v6-i3/3081.

Malaysian Blueprint 2013-2025. (2013). Moe.Gov.My. https://www.moe.gov.my/menumedia/media-cetak/penerbitan/dasar/1207-malaysiaeducation-blueprint-2013-2025/file.

Pajares, F., \& Urdan, T. (2006). Self-efficacy Beliefs of Adolescents. Greenwich, CT: Information Age Publishing.

Rahimi, A., \& Abedini, A. (2009). The Interface between EFL Learners' Self-Efficacy concerning Listening Comprehension and Listening Proficiency. Novitas Royal, 3(1), 14-28.

https://www.researchgate.net/publication/275276911_The_Interface_between_EFL_Lea rners'_Self-Efficacy_Concerning_Listening_Comprehension_and_Listening_Proficiency

Raoofi, S., Tan, H. B., \& Chan, H. S. (2012). Self-efficacy in Second/Foreign Language Learning Contexts. English Language Teaching, 5 (11),61-73.

https://doi.org/10.5539/elt.v5n11p60

Tan, T. G., Ismail, H. N., Hoe, F. T., \& Ho, C. C. (2016). The Motivation of Undergraduates Learning Mandarin as a Foreign Language. E-Academia Journal UiTMT, 5(1), 1-11. http://journale-academiauitmt.uitm.edu.my/v2/.

Tan, T. G., Ooi, A. K., \& Hairul, N. I. (2012). The Orientations for Learning Mandarin amongst Malay Undergraduate Students. International Journal of Humanities and Social Science. 2 (12). http://www.ijhssnet.com/journals/Vol_2_No_12_Special_Issue_June_2012/15.pdf.

Tan, T. G., \& Hoe, F. T. (2007). Research and contribution of University Technology MARA to the teaching Chinese language as a foreign language. Proceedings of 3 rd International Forum on Chinese Language Teaching. National Taiwan Normal University.Tomasello, M. (2003). Constructing a language: A usage-based theory of language acquisition. USA: First Harvard University Press.

Turner, E. A., Chandler, M., \& Heffer, R. W. (2009). The influence of parenting styles, Achievement motivation and self-efficacy on academic performance in college students. Journal of College Student Development. 50(3), 337346.https:// doi.org/10.1353/csd.0.0073.

Tseng, W., \& Schmitt, N. (2008). Toward a model of motivated vocabulary learning: A structural equation modelling approach. Language Learning, 58, 357-400. https://doi.org/10.1111/j.1467-9922.2008. 00444.x.

Tilfarlioğlu, F. T., \& Ciftci, F. S. (2011). Supporting Self-efficacy and Learner Autonomy in Relation to Academic Success in EFL Classrooms (A Case Study). Theory and Practice in Language Studies, 1(10), 1284-1294. http://doi.org/10.4304/tpls.1.10.1284-1294.

Yin, B. Y. (1984). Quantitative analysis of Chinese morpheme. Chinese,5, 338-347. (in Chinese).

Yuan, C. F., \& Huang, C. N. (1998). Chinese morphemes and compounds: A corpus study [Chinse language]. Applications of Languages and Writing Systems,3, 7-12.

Waninge, F., Dörnyei, Z., \& De Bot, K. (2014). Motivational dynamics in language learning: Change, stability, and context. The Modern Language Journal, 98, 704-723. https://doi.org/10.1111/j.1540-4781.2014. 12118.x. 
Zhao, A. P., \& Whitchurch, A. (2011). Anxiety and its Associated Factors in College-Level Chinese Classrooms in the U.S. Journal of Chinese Language Teachers Association, 46, 21-47.

Zhao, A. Y., Guo, Y., Biales, C., \& Olszewski, A. (2016). Exploring learner factors in second language (L2) incidental vocabulary acquisition through reading. Reading in a Foreign Language, 28(2), 224- 245.

https://www.researchgate.net/publication/309157391_Exploring_learner_factors_in_sec ond_language_L2_incidental_vocabulary_acquisition_through_reading

Zhang, L. J. (2001). Exploring variability in language anxiety: Two groups of PRC students learning ESL in Singapore. RELC Journal, 32(1), 73-94.

http://dx.doi.org/10.1177/003368820103200105 